\title{
Laminate veneers: mimetizing nature through anatomical remodeling - case report
}

\author{
Dayla Thyeme Higashi ${ }^{\mathrm{a}}$, Márcio Grama Hoeppner ${ }^{\mathrm{b}}$, Raquel Sano Suga Terada ${ }^{\mathrm{a}}$, \\ Mariana Paizana Iris ${ }^{c}$, Renato Batista $\mathrm{Cogo}^{c}$
}

\begin{abstract}
OBJECTIVE: Dental aesthetics is one of the areas of dentistry that has most advanced in terms of procedures, techniques and materials. Changes in color, shape, and texture are commonly cited as grounds for complaint, which are sometimes characterized by details, making the work challenging. The objective of this work is to report the planning and execution of a clinical case of smile harmonization with ceramic laminates for remodeling smile.

CASE DESCRITION: A male patient consulted a specialist to refine the appearance of his smile that already had a satisfactory pattern of color and texture. The planning was started using digital smile planning, followed by diagnostic waxing of the elements involved. The planning approval took place through the Mock up. The dental grinding performed was minimal and followed a silicone wear guide. The pieces were made in lithium disilicate and installed under absolute isolation according to the cementing protocol of the material. The finishing and polishing completed the installation of the pieces, removing excesses and guaranteeing periodontal compatibility.

CONCLUSION: We conclude that indirect aesthetic treatments currently have a minimally invasive character and are highly accepted due to their ability to remodel the smile with perfection and naturalness.
\end{abstract}

Keywords: dental restoration; esthetics; diastema.

\section{Laminados cerâmicos: mimetizando a natureza através da remodelação anatômica - relato de caso}

\section{RESUMO}

INTRODUÇÃO: A estética dental é uma das áreas da odontologia que tem mais avançado em termos de procedimentos, técnicas e materiais. Alterações na cor, forma e textura são comumente citados como motivos para queixa, que às vezes são caracterizados por detalhes, tornando o trabalho desafiador. O objetivo deste trabalho é relatar o planejamento e a execução de um caso clínico de harmonização do sorriso com laminados cerâmicos.

RELATO DE CASO: Um paciente do sexo masculino consultou um especialista para refinar a aparência de seu sorriso que já tinha um padrão satisfatório de cor e textura. O planejamento foi iniciado usando o planejamento digital do sorriso, seguido pelo enceramento diagnóstico dos elementos envolvidos. A aprovação do planejamento ocorreu através do Mock up em resina bisacrílica. O preparo dental realizado foi mínimo e seguiu uma guia de desgaste de silicone. As peças foram feitas em dissilicato de lítio e instaladas sob isolamento absoluto de acordo com o protocolo de cimentação do material. O acabamento e o polimento eliminaram os excessos e garantiram a compatibilidade periodontal.

CONCLUSÃO: Concluímos que os tratamentos estéticos indiretos atualmente têm um caráter minimamente invasivo e são altamente aceitos devido à sua capacidade de remodelar o sorriso com perfeição e naturalidade.

Palavras-chave: restauração dental; estética; diastema.

\footnotetext{
State University of Maringa, Paraná, Brazil

b State University of Londrina, Paraná, Brazil

c Paranaense University, Paraná, Brazil
}

\section{Correspondence Dayla Thyeme Higash daythyeme@gmail.com \\ Received: October 9, 2017 Accepted: June 22, 2018}

Conflict of Interests: The authors state that there re no financial and personal conflicts of interest that could have inappropriately influenced their work.

Copyright: () 2018 Higashi et al licensee EDIPUCRS.

This work is licensed under a Creative Commons Attribution 4.0 International License. 


\section{INTRODUCTION}

Dental treatments involving the search for a beautiful smile, as well as the patient's expectations regarding purely aesthetic treatments have grown in demand [1]. Thorough clinical planning of all stages, as well as identification of patient expectations are key to predictability and ultimate success [2].

In the planning of the new smile, studying the patient's face is closely related to the desired harmony, so the facial bone structures, periodontal tissue, and lips should be taken into consideration [3]. Aesthetic smile remodeling may require other procedures besides restorative treatment, and multi-professional planning is highly indicated $[4,5]$. Nowadays useful tools are available for planning the new smile, both for the study and predictability of the dental surgeon, and for the approval of the final result by the patient.

Digital planning through photographs and image editing software is the most effective means of communication between dentists and ceramists. Through this device, best known by the name DSD (Digital Smile Design), it is possible to virtually simulate the result to be achieved, in the same way that it allows visualization of the possibilities of work within the same case and the perception of the patient, who, in a very early stage of the treatment receives a sample of the possibilities at finalization $[3,6]$. A second artifice that should always be used in the planning stages of aesthetic dentistry is diagnostic waxing followed by a mock-up in bisacrylic resin. This step allows the projection of the planning directly into the patient's mouth, as well as verifying any occlusion or possible interferences that may represent problems $[1,7]$.

Teeth with shape alterations may be adequate for the patient's needs with direct and indirect restorative treatment. Indirect restorative treatment with ultrathin ceramic laminate is an option with high aesthetic quality, great longevity, and low failure rates in enamel adhesion, as well as being conservative due to the limited grinding of healthy tooth structure and good biotolerance by the periodontal tissues [8-11].

The objective of this work is to report and discuss the planning and execution of a smile harmonization with ultrafine indirect restorations in lithium disilicate.

\section{CASE DESCRIPTION}

Male patient, 21 year old, sought attendance at the Multidisciplinary Clinic of Universidade Paranaense (UNIPAR), dissatisfied with the harmony of his smile. The patient's complaint was related to the presence of interdental spaces and the shape of his teeth.

In the clinical evaluation, the presence of diastema between the central and lateral incisors on both sides of the upper arch was verified. Elements 12 and 22 presented small dimensions, which resulted in diastema. On the other hand, the canines presented as excessively long, contrasting with the lateral incisors which conferred disharmony to the patient's smile (Figure $\mathbf{1}$ and $\mathbf{2}$ ).
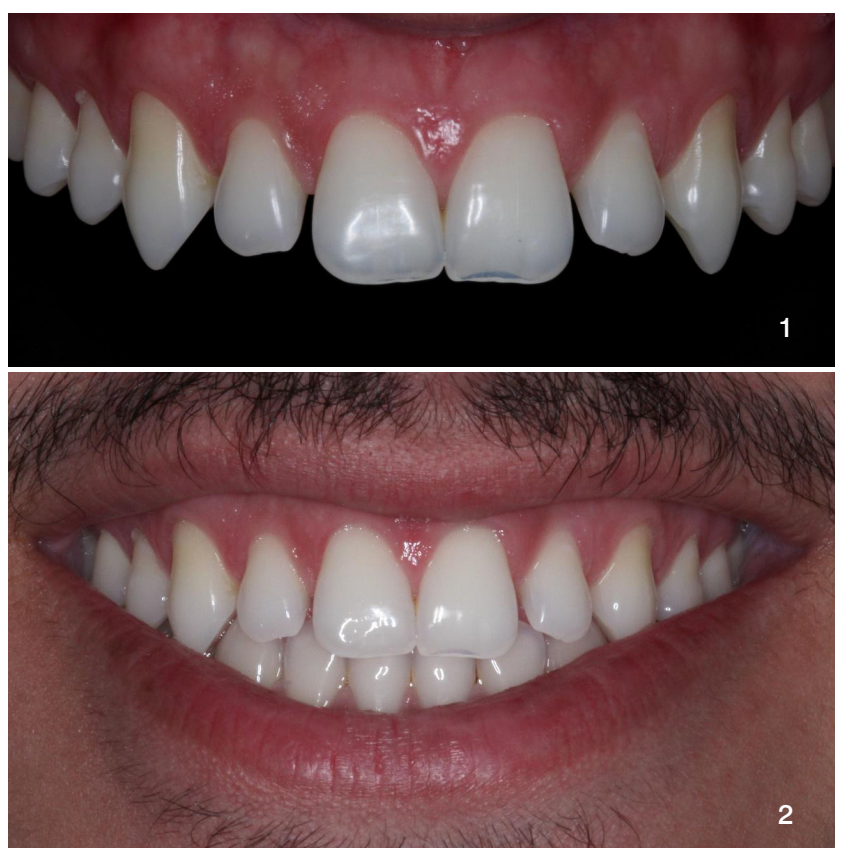

Figure 1 and 2. Approximate view of the initial appearance of the patient's smile.

Intraoral and extraoral photographs were used for the case study and planning, through DSD, where the proportions of height, width, and lines, facial and dental, were verified. The planning covered 8 dental elements, extending from the first right premolar to the first left premolar of the maxilla. This was presented to the patient, who agreed with the elaborated intervention (Figure 3 and $\mathbf{4}$ ).

After the digital planning step, upper and lower arch impressions were performed with silicone addition (Express XT, 3M ESPE, St. Paul, United States) for initial registration and waxing based on the DSD (Figure 5). The proof from the virtual planning specifically for the patient's mouth occurs through a procedure called mock-up, in which a silicone guide with a copy of the wax is filled with bisacrylic resin (Protemp 4, 3M ESPE, St. Paul, United States) for application on the dental elements. With the mock-up on the teeth we verified the functions of protrusion and laterality, as well as possible occlusal interferences after addition of the structure. The conditions were favorable with no identification of interference (Figure 6).

As the dental remainder presented good coloration and vitality, corrections with thin ceramic slides were feasible. Preparation of the dental structure was minimally invasive. Silicone guides were used to verify the presence of adequate spaces for dental contact lenses (Figure 7). Specific diamond tips for dental preparations were used only in the locations and teeth identified as presenting a lack of space (Kit Facetas Laminadas, KG Sorensen, Cotia, São Paulo, Brazil). The tips with thicker granulations initiated the selective grinding and demarcation of cervical and proximal limits (Figure 8). The preparation of the dental structure was refined with extrafine granulated diamond tips and serial abrasive silicone tips (Viking, KG Sorensen, Cotia-SP, Brazil) (Figure 9). 
9
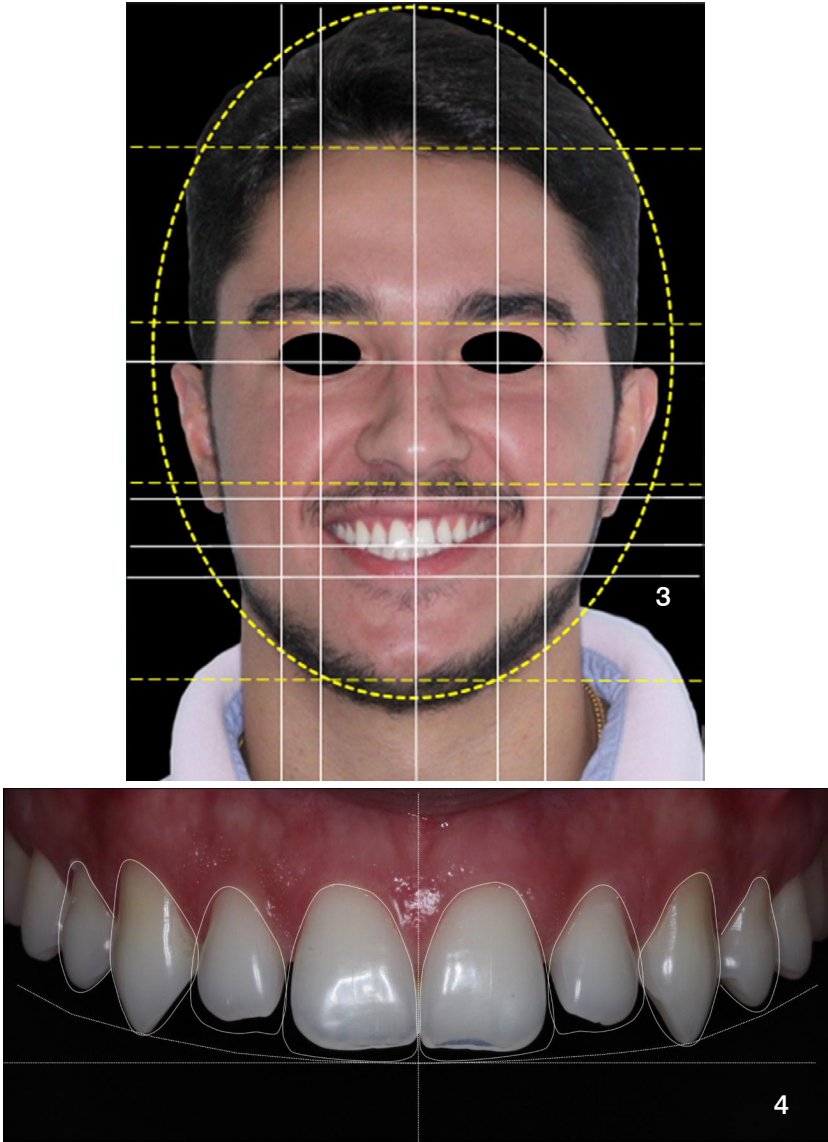

Figure 3 and 4. Facial measurements and digital smile planning (DSD)

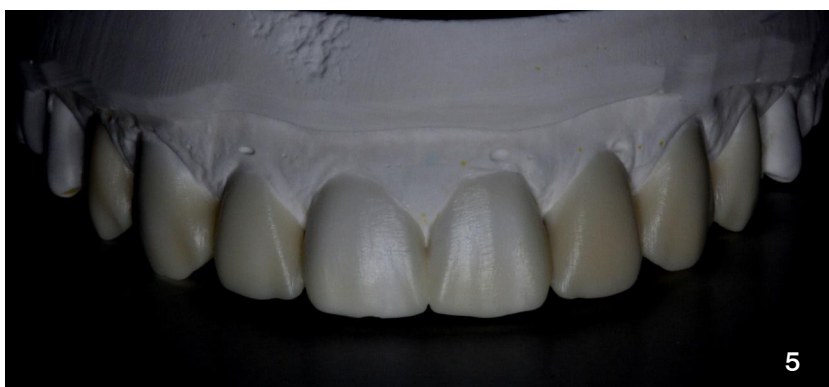

Figure 5. Diagnostic waxing.

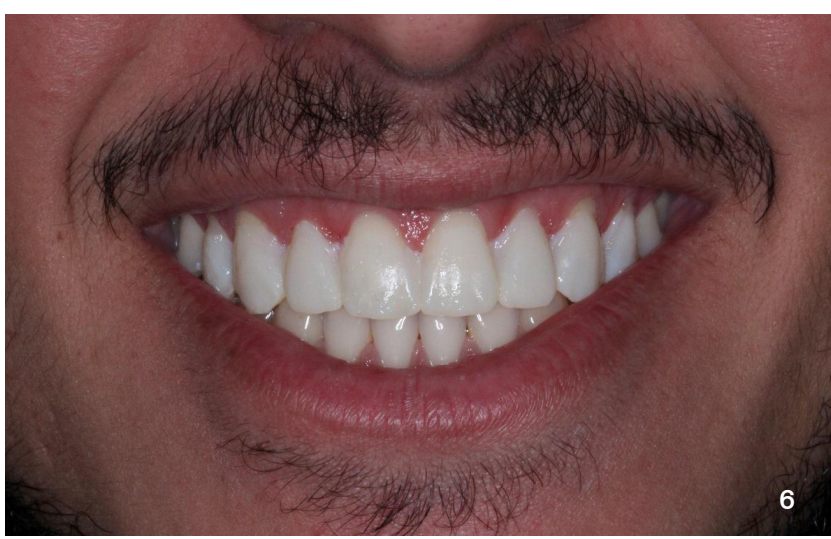

Figure 6. Mock-up test.

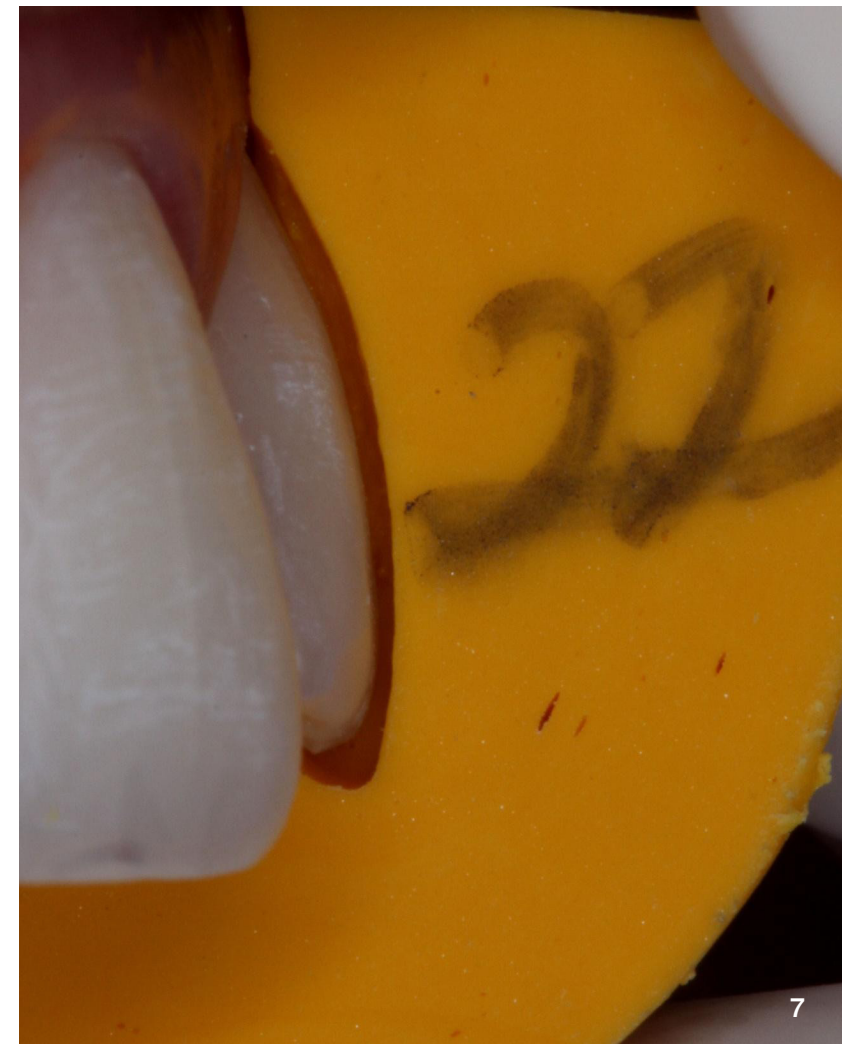

Figure 7. Silicone guides positioned to verify the presence of adequate spaces for dental contact lenses.

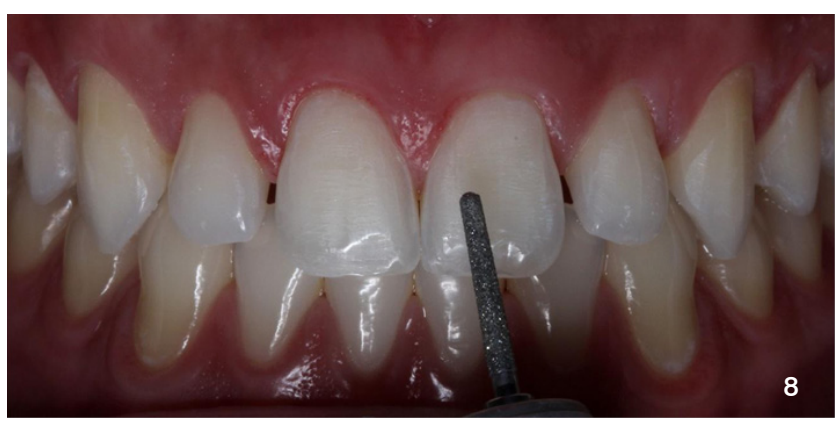

Figure 8. Dental preparation, selective grinding and demarcation of cervical and proximal limits.

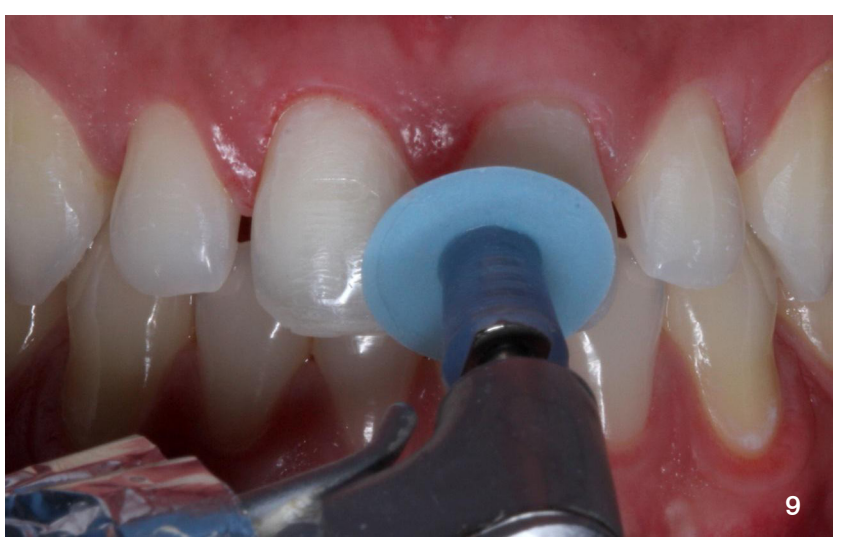

Figure 9. Polishing of tooth structure. 
The work molding must faithfully copy the cervical term and all dental surfaces, ensuring adequate substrate for the prosthesis work and subsequent passive fitting of the ceramic laminates. The molding was performed through the double-impression technique using heavy addition silicone paste (Express XT, 3M ESPE, St. Paul, United States) with subsequent light addition silicone paste (Express XT, 3M ESPE, St. Paul, United States) added to the mold (Figure 10).

Dental color was recorded in photographs as the chosen shade should be as close as possible to the VITA scale options (VITA Classical, Wilcos, Petrópolis, Rio de Janeiro, Brazil). The information and molding were sent to the prosthetic laboratory for manufacture of contact lens type ceramic laminates. As the grinding performed on the tooth structure was minimal and discrete, there was no need for temporary measures.

The specimens were made from vitreous ceramics reinforced with lithium disilicate crystals (EPS e-max Press, Ivoclar Vivadent, Schaan, Liechtenstein), mean thickness $0.7 \mathrm{~mm}$, and encompassed the DSD and mock-up planning specifications (Figure 11).

The first test was a dry test of the pieces on the dental structure (Figure 12). Only one piece (right side) did not present a passive fit. The site of interference was identified and a small alteration was made to the tooth structure with a conical truncated diamond tip (Viking, KG Sorensen, Cotia, SP, Brazil), which was sufficient for the adjustment.

The wet test is performed with Try-in paste (AllcemVeneer, FGM, Florianópolis, Santa Catarina, Brazil), which simulates the coloration of the resin cement. In this step it is possible to make small corrections to the coloring of the laminate, or if there is no need, which is the ideal, a neutral coloration is chosen.

The cementation protocol is related to the type of material and its thickness; in this case pieces of lithium disilicate are acid sensitive and have adequate thickness for the passage of light. The adhesive procedure was initiated by applying 10\% hydrofluoric acid (Condac Porcelana, FGM Produtos Odontológicos, Joinville, Santa Catarina, Brazil) for 20 seconds (Figure 13), followed by abundant washing. Removal of the remaining crystals from the chemical action performed with the hydrofluoric acid was performed with $37 \%$ phosphoric acid (Condac 37, FGM Produtos Odontológicos, Joinville, Santa Catarina, Brazil) for 60 seconds with active movements, followed by washing (Figure 14). Silanization (Prosil, FGM Produtos Odontológicos, Joinville, Santa Catarina, Brazil) of the parts ensures compatibility between the material and adhesive/cement, its application was carried out actively and a wait of 1 minute was allowed for volatization Figure 15). The adhesive (Ambar, FGM Produtos Odontológicos, Joinville, Santa Catarina, Brazil) was applied to the pieces with a microbrush, without photoactivation (Figure 16).

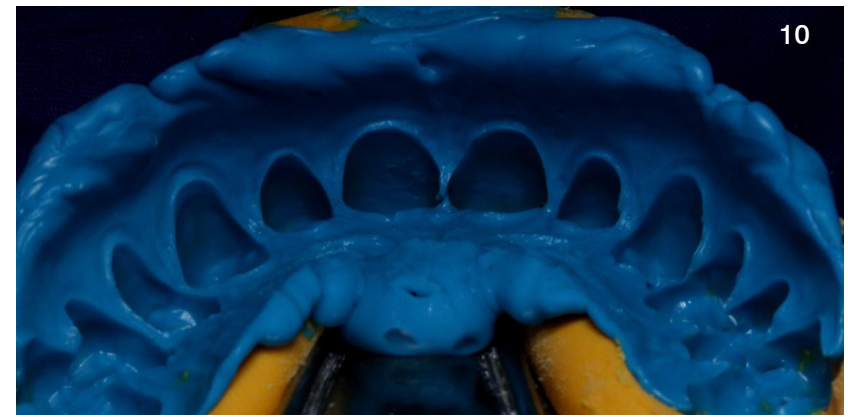

Figure 10. Molding through the double-impression technique, of dental elements prepared.

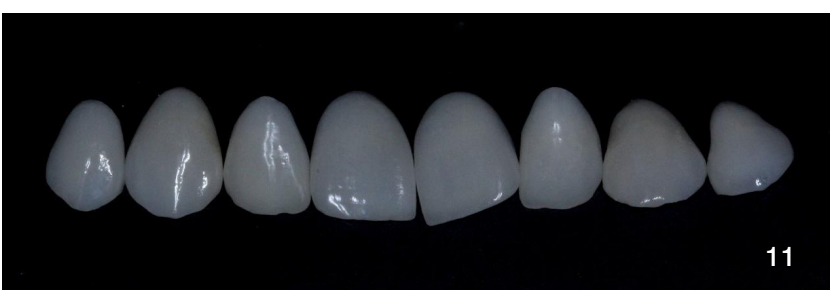

Figure 11. Indirect contact lens type restorations made with lithium disilicate.

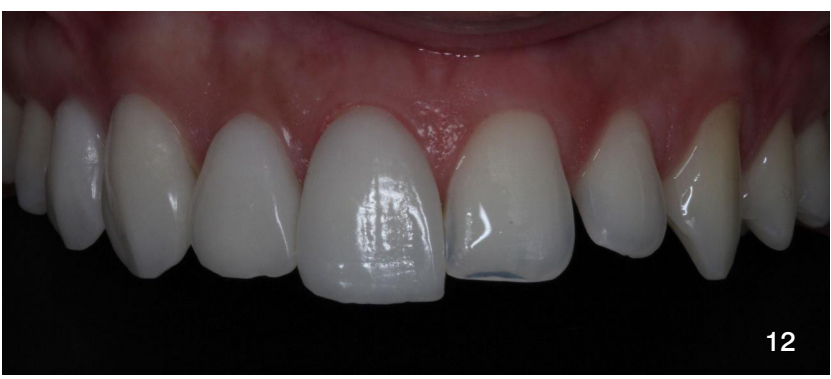

Figure 12. Dry proofs of the laminates.

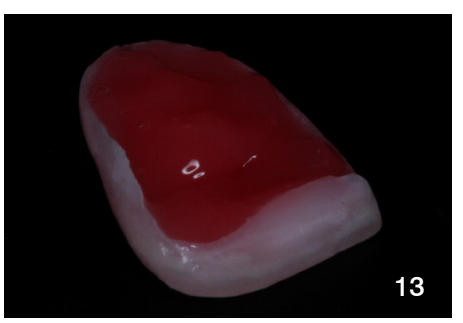

Figure 13. Conditioning with $10 \%$ hydrofluoric acid for 20 seconds.



Figure 14. Attack with $37 \%$ phosphoric acid for 60 seconds to removal of the remaining crystals from the chemical action performed with the hydrofluoric acid. 


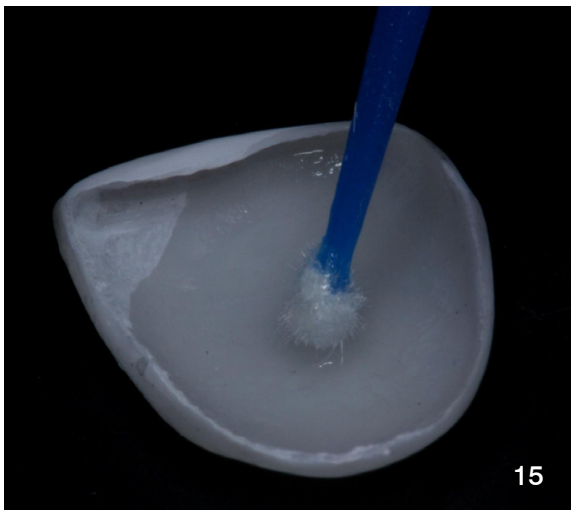

Figure 15. Silanization.

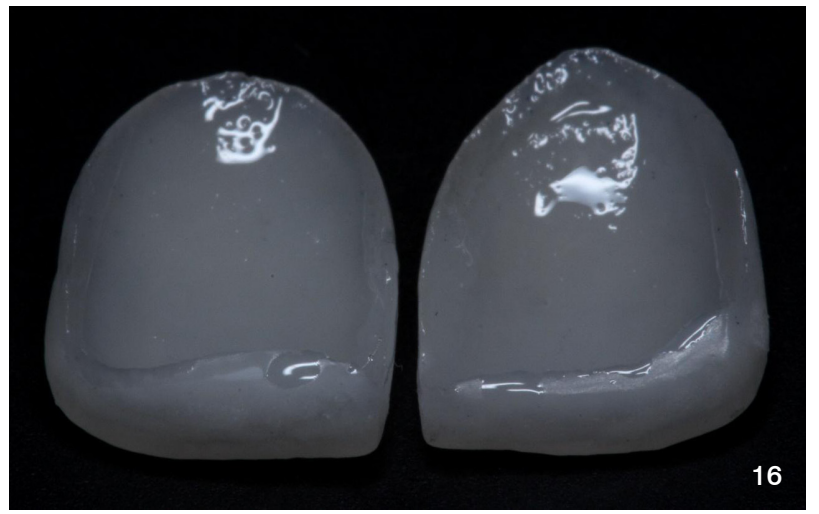

Figure 16. Adhesive application without photoactivation.
The operative field was isolated in a modified form (canoe isolation), allowing wide exposure of the dental cervical. An ultrafine retractor wire was inserted into the gingival sulcus with the intention of blocking cement residues that may remain in the periodontal region and controlling the crevicular fluid. The dental structure underwent acidic conditioning (Figure 17) (CONDAC 37, Produtos Odontológicos, Joinville, Santa Catarina, Brazil) and adhesive system application (Figure 18) (Ambar, Produtos Odontológicos, Joinville, Santa Catarina, Brazil) which was photoactivated for 30 seconds in each tooth. The resin cement chosen is activated strictly by photoactivation, compatible with the thickness of the pieces. Each laminate was filled with resin cement in Trans color (Figure 19) (AllcemVenner, FGM Produtos Odontológicos, Joinville, Santa Catarina, Brazil) and placed in position. The excess cement was removed with a brush, dental floss, and spatulas, to then be polymerized (Bluephase N, Ivoclar Vivivent, Schaan, Liechtenstein) for 60 seconds on each face (Figure 20).

After cementing the eight laminate veneers, the rubber insulation was removed as was the retractor wire. The occlusal contacts were verified regarding laterality, protrusion, and intercuspation. The finishing and polishing was carried out with fine and extra fine rubbers for porcelain (Exa-cerapol, Edenta AG, Hauptstrasse 7, Switzerland).

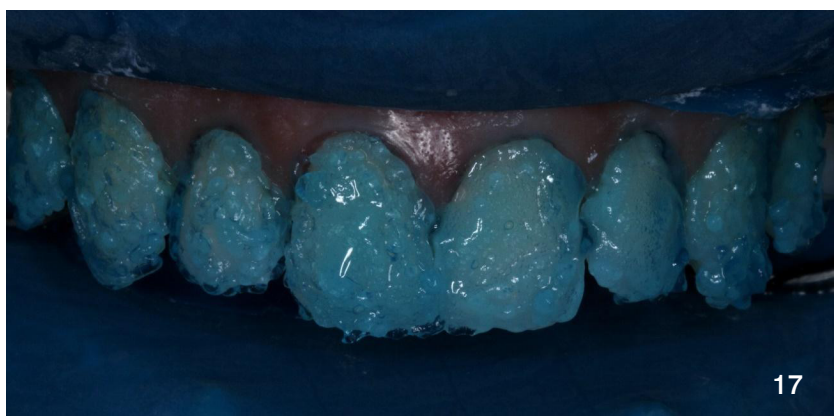

Figure 17. Acid conditioning of the dental structure.
The final result was evaluated as extremely satisfactory, met the expectations of the patient, and the treatment ended successfully (Figures 21 and 22).

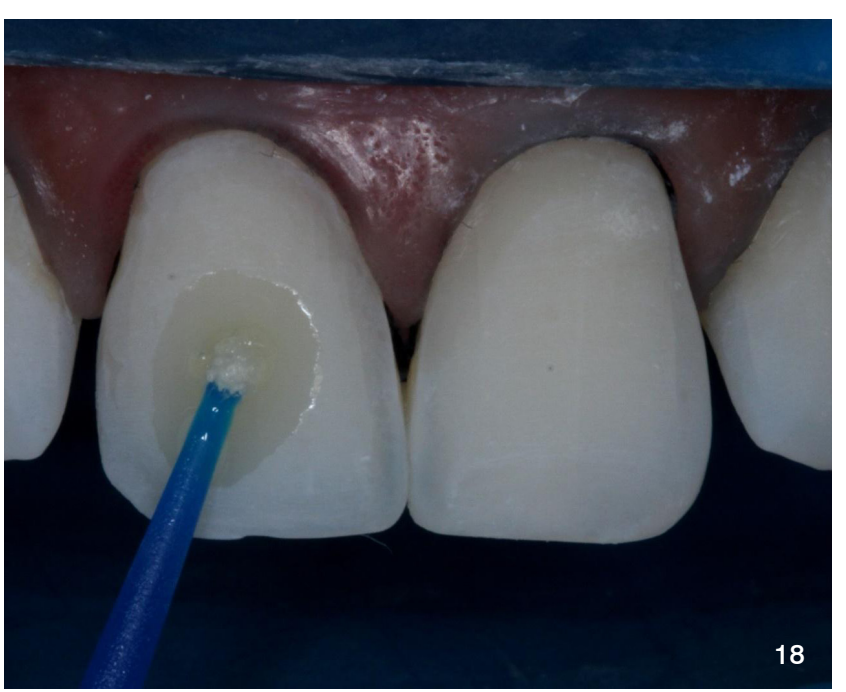

Figure 18. Adhesive system application.

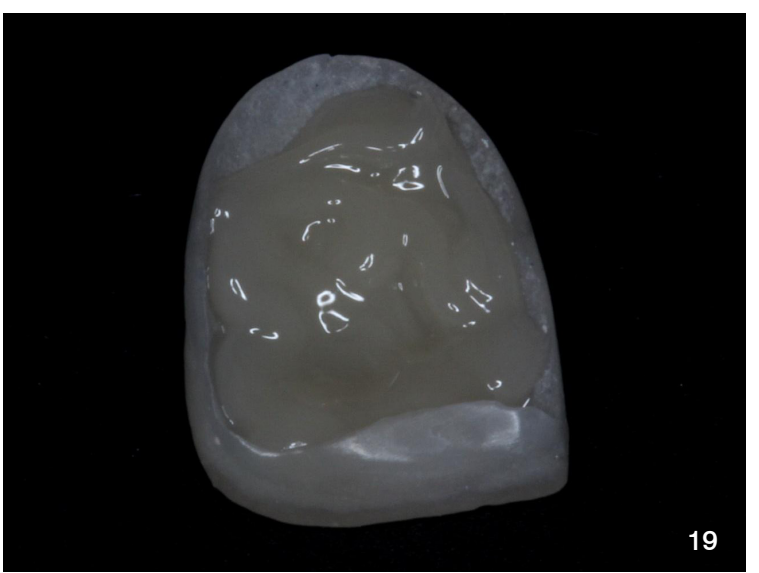

Figure 19. Laminate veneers filled with resin cement in trans color. 


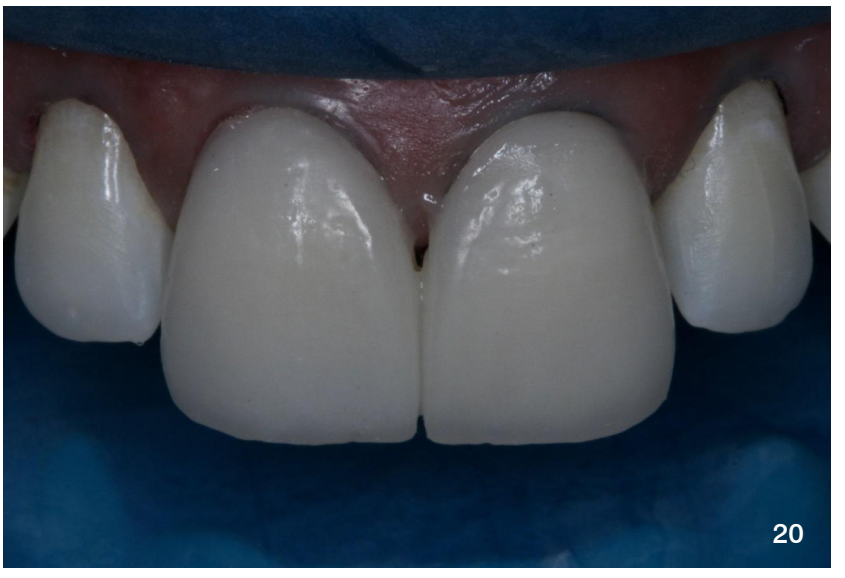

Figure 20. Incisive laminate veneers immediately after cementation.
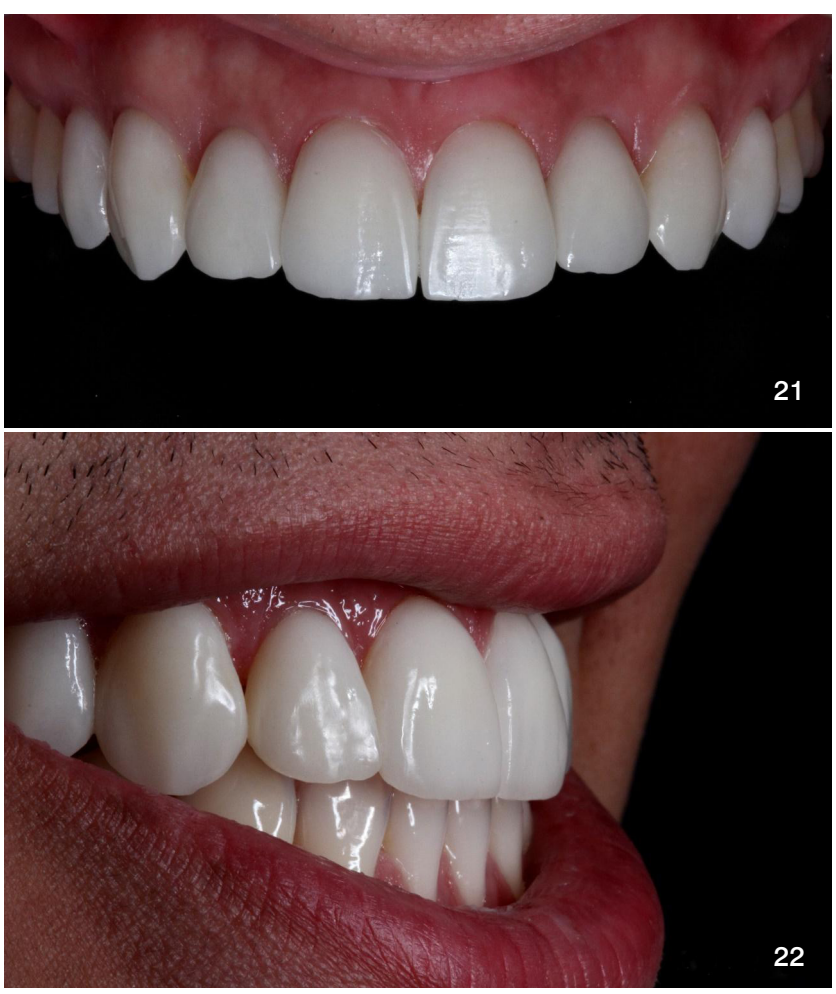

Figure 21 and 22. Final appearance after cementation.

\section{DISCUSSION}

This case report illustrates the type of situation that has become common today. The search for harmony of the smile, balancing the facial characteristics, and reaching the ideal of beauty desired by patients, has led dental surgeons to specialize in treatments with a high standard of aesthetic results [3]. For this, the use of cutting-edge technology and materials are fundamental for the success and satisfaction of patients who are increasingly well informed, with concepts founded on beauty standards.
The challenge in this type of treatment begins with the anamnesis. Understanding the reason for dissatisfaction with appearance and possible expected outcomes impacts on what is feasible and the particular limitations of each case. Facial beauty has had great importance since ancient societies [12], in this group the teeth framed by the lips play an important role in the personal characterization3.

The evolution of dental ceramics and adhesive procedures has provided excellent aesthetic results in indirect restorative treatments, promoting their popularity $[13,14]$. The great acceptance of treatment with dental contact lenses is due to the preparations being minimally invasive, having great capacity to mimic the dental characteristics, being well tolerated biologically by periodontal tissue, and being mechanically similar to human enamel [15].

Despite all the advantages presented, the predictability of the final results is the great differential of the current indirect treatments. Through digital planning and based on established aesthetic precepts, the treatment and how it should ideally be performed is predicted [1]. In addition, the DSD method provides objective communication with the patient and prosthesis laboratory, allowing identification of possibilities, limitations, and whether the expectations were considered $[16,17]$.

The real test of virtual planning is initiated by waxing on the plaster model of the initial case, a procedure also called Wax-up, and subsequent transfer in self-curing resin to the patient's mouth, the mock-up [17]. Minor distortions in the initial planning may occur, a limitation of the previous indirect restoration procedures; however their execution can be repeated and adjusted until the dentist and patient are completely satisfied [1].

The minimally invasive preparation is crucial for the longevity of the restorations [18], excessive dental grinding and consequent exposure of the dentin results in a decrease in adhesive strength and less preservation of the integrity of the restoration [18]. In the clinical case presented, the need for grinding was verified through a silicone guide that limited the removal of enamel to the retentive areas and those without space for the ceramic. Even in areas where grinding was performed, the amount removed was minimal. In situations where the color of the dental remnant poses no problem, it is possible to use contact lenses with a thickness of 0.3 to 1.2 millimeters.

Fractures and detachments are the most commonly reported problems related to indirect restorations [11]. The causes are usually associated with occlusal factors or behavioral differences in the substrate [11]. Ceramics made in lithium disilicate, such as the laminas of this clinical case, present good flexibility, close to the dental structure. Favoring a good prognosis, the patient did not have any occlusal interference or para-functional habits.

\section{CONCLUSION}

Increasingly high aesthetic expectations have raised the standard of planning and execution in dentistry. Purely 
aesthetic procedures are a new clinical reality, allied with advanced technology, materials, and techniques which produce excellent results derived from good planning, combining clinical success with meeting demanding expectation.

\section{REFERENCES}

1. Pimentel W, Teixeira ML, Costa PP et al. Predictable Outcomes with Porcelain Laminate Veneers: A Clinical Report. J Prosthodont 2016;25: 335-40. https://doi.org/10.1111/jopr.12413

2. McLaren EA, Garber DA, Figueira J. The Photoshop Smile Design technique (part 1): digital dental photography. Compend Contin Educ Dent 2013;34:772, 4, 6 passim.

3. Alrizqi AM, Mohammed YH; Albounni, R. Smile Design: Assessment and Concept. Int J of Cur Res 2015;7:24746-50. https/doi/10.1111/j.17088240.2011.00428.x

4. Da Cunha LF, Pedroche LO, Gonzaga CC, Furuse AY. Ultimate ceramic veneer: a laboratory-guided preparation technique for minimally invasive laminate veneers. thickness porcelain laminate veneers. J Prosthet Dent 2014;112:1315-8. https://doi.org/10.1016/j.prosdent.2014.05.028

5. Sriram G, Nagalakshmi S, Balachandar K, Madhusudan K. Interdisciplinary approach for improved esthetic results. J Pharm Bioallied Sci 2014;6: 192-5. https://doi.org/10.4103/0975-7406.137466

6. Zanardi PR, Laia Rocha Zanardi R, Chaib Stegun R, Sesma N, Costa BN, Cruz Laganá D. The Use of the Digital Smile Design Concept as an Auxiliary Tool in Aesthetic Rehabilitation: A Case Report. Open Dent J 2016;10:28-34. https://doi.org/10.2174/1874210601610010028

7. Zavanelli AZRA, Mazaro JVQ, Santos D, Fálcon-Antenucci RM. Tratamento cosmético com lentes de contato e laminados cerâmicos. Archives of Health Investigation 2015;4:10-7.

8. Peumans M, Van Meerbeek B, Lambrechts P, Vanherle G. Porcelain veneers: a review of the literature. Journal of dentistry 2000;28:163-77. https://doi.org/10.1016/S0300-5712(99)00066-4
9 Piemjai M. Arksornnukit M. Compressive fracture resistance of porcelain laminates bonded to enamel or dentin with four adhesive systems. J Prosthod 2007:16:457-64. https://doi.org/10.1111/j.1532$849 \times 2007.00227 \times$

10. Layton DM, Clarke M, Walton TR. A systematic review and meta-analysis of the survival of feldspathic porcelain veneers over 5 and 10 years. Int Prosthodont 2012;25:590-603

11. Gurel G, Sesma N, Calamita MA, Coachman C, Morimoto S. Influence of enamel preservation on failure rates of porcelain laminate veneers. Int J Periodontics Restorative Dent 2013;33:31-9. https://doi.org/10.11607/ prd. 1488

12. Okuda W. Smile Design 1.0: Learning from our past to meet the current challenge for predictable success. Gen Dent 2015;63:16-8.

13. Seghi RR, Sorensen JA. Relative flexural strength of six new ceramic materials. Int J Prosthodont 1995:8:239-46.

14. Walter RD, Raigrodski AJ. Critical appraisal: Clinical considerations for restoring mandibular incisors with porcelain laminate veneers. J Esthet Restor Dent 2008;20:276-81. https://doi.org/10.1111/j.17088240.2008.00192.x

15. Abu-Hussein MW, Watted N, Abdulgani A. Porcelain Laminates - Current State of The Art: A Clinical Review. Int J Dental and Health Sci 2015;2: 323-33.

16. Coachman CC, Calamita M. Digital Smile Design: a tool for treatment planning and communication in esthetic dentistry. Quintessence Dent Technol 2012;35:103-11

17. Lin WS, Zandinejad A, Metz MJ, Harris BT, Morton D. Predictable Restorative Work Flow for Computer-Aided Design/Computer-Aided Manufacture-Fabricated Ceramic Veneers Utilizing a Virtual Smile Design Principle. Oper Dent 2015;40:357-63. https://doi.org/10.2341/13-295-S

18. De Andrade OS, Hirata R, Celestrino M, Siqueira S. Nahas R. Ultimate ceramic veneer: a laboratory-guided preparation technique for minimally invasive laminate veneers. J Calif Dent Assoc 2012;40:489-94. 